\title{
PtSnIr/C Anode Electrocatalysts: Promoting Effect in Direct Ethanol Fuel Cells
}

\author{
Júlio C. M. Silva, ${ }^{a}$ Rodrigo F. B. De Souza, ${ }^{a}$ Mayara A. Romano, ${ }^{a}$ Melina D’Villa-Silva, ${ }^{a}$ \\ Marcelo L. Calegaro, ${ }^{b}$ Peter Hammer, ${ }^{c}$ Almir O. Neto ${ }^{d}$ and Mauro C. Santos ${ }^{*, a}$ \\ ${ }^{a}$ Laboratório de Eletroquímica e Materiais Nanoestruturados, Centro de Ciências Naturais e Humanas, \\ Universidade Federal do ABC, Rua Santa Adélia, 166, 09210-170 Santo André-SP, Brazil \\ ${ }^{b}$ Grupo de Materiais Eletroquímicos e Métodos Eletroanalíticos, Instituto de Química de São Carlos, \\ Universidade de São Paulo, CP 780, 13566-590 São Carlos-SP, Brazil \\ 'Instituto de Química, Universidade Estadual de São Paulo, 14800-060 Araraquara-SP, Brazil \\ ${ }^{d}$ Instituto de Pesquisas Energéticas e Nucleares-Comissão Nacional de Energia Nuclear (IPEN-CNEN), \\ Av. Prof. Lineu Prestes, 2242, 05508-900 São Paulo-SP, Brazil
}

\begin{abstract}
Este estudo investiga o efeito promotor de anodos eletrocatalisadores do tipo PtSnIr/C (1:1:1), preparados pelo método de precursor polimérico, na reação de oxidação de etanol em uma célula a combustível de etanol direto (DEFC). Todos os materiais usados foram metal $20 \% \mathrm{~m} / \mathrm{m}$ com relação a carbono. Análise por espectroscopia fotoelétrica de raios X (XPS) mostrou a presença de $\mathrm{Pt}, \mathrm{PtOH}_{2}, \mathrm{PtO}_{2}, \mathrm{SnO}_{2}$ e $\mathrm{IrO}_{2}$ na superfície do eletrocalisador, indicando uma possível estrutura de partícula revestida. Análise por difratometria de raios X (XRD) indicou Pt e Ir metálicos assim como a formação de uma liga com Sn. Utilizando eletrocatalisadores do tipo PtSnIr/C preparados para este estudo com quantidades de Pt duas vezes menor que em eletrocatalisadores do tipo PtSn/C E-tek, foi possível obter a mesma densidade de potência máxima encontrada para o material comercial. O produto de reação principal foi ácido acético provavelmente devido a presença de óxidos, neste caso o mecanismo bifuncional é predominante, mas um efeito eletrônico não deve ser descartado.
\end{abstract}

This study investigates the promoting effect of PtSnIr/C (1:1:1) electrocatalyst anode, prepared by polymeric precursor method, on the ethanol oxidation reaction in a direct ethanol fuel cell (DEFC). All of the materials used were $20 \%$ metal $\mathrm{m} / \mathrm{m}$ on carbon. X-ray photoelectron spectroscopy (XPS) analysis showed the presence of Pt, $\mathrm{PtOH}_{2}, \mathrm{PtO}_{2}, \mathrm{SnO}_{2}$ and $\mathrm{IrO}_{2}$ at the electrocatalyst surface, indicating a possible decorated particle structure. X-ray diffractometry (XRD) analysis indicated metallic Pt and Ir as well as the formation of an alloy with Sn. Using the PtSnIr/C electrocatalyst prepared here with two times lower loading of Pt than PtSn/C E-tek electrocatalyst, it was possible to obtain the same maximum power density found for the commercial material. The main reaction product was acetic acid probably due to the presence of oxides, in this point the bifunctional mechanism is predominant, but an electronic effect should not be discarded.

Keywords: PtSnIr , ethanol oxidation reaction, electrocatalysis, nanostructured materials, fuel cells

\section{Introduction}

Polymeric exchange membrane fuel cells (PEMFCs) have been extensively studied due to their mobile, stationary and portable applications. ${ }^{1,2}$ Among the PEMFCs, direct alcohol fuel cells (DAFCs) have the advantage that the liquid fuel can be more easily stored and handled compared to hydrogen. ${ }^{3}$

*e-mail: mauro.santos@ufabc.edu.br
Ethanol is a more attractive fuel alcohol for PEMFC applications when compared with methanol because it is much less toxic, can be produced at a large scale from agricultural products or biomass, ${ }^{4,5}$ and is more energetic $\left(8 \mathrm{kWh} \mathrm{kg}^{-1}\right.$ vs. $\left.6.1 \mathrm{kWh} \mathrm{kg}^{-1}\right){ }^{6}$ For these reasons, direct ethanol fuel cells (DEFCs) should achieve similar performance levels as direct methanol fuel cells.

However, the complete electrooxidation of ethanol is a 12-electron process, which is a practical challenge for the effectiveness of the catalysts. Pt is the most used metal for 
the oxidation of this alcohol, and its electrocatalytic activity can be improved by the addition of other metals such as $\mathrm{Ru},{ }^{7-10} \mathrm{Sn},{ }^{8,10-13} \mathrm{Rh}^{14,15}$ and Ce. ${ }^{16,17}$ However, these metals need to break the $\mathrm{C}-\mathrm{C}$ bond at low temperatures, ${ }^{5,18}$ and generate $\mathrm{CO}_{2} \cdot{ }^{8,19}$ Thus, the investigation of the catalytic capacity of these materials in the ethanol oxidation process has become a priority.

Metallic iridium and $\mathrm{IrO}_{2}$ are used as catalysts for oxygen evolution and reduction reactions in regenerative polymer electrolyte fuel cells..$^{20,21}$ The authors described that $\mathrm{IrO}_{2}$ has high activity towards $\mathrm{CO}_{\text {ads }}$ electrooxidation. Moreover, these catalysts also exhibit excellent performance in the electrocatalysis of methanol in direct methanol fuel cells (DMFCs). ${ }^{22,23}$ Chen et al. ${ }^{24}$ showed that a thin layer of $\mathrm{IrO}_{2}$ on $\mathrm{Ti} / \mathrm{IrO}_{2} / \mathrm{Pt}$ improved the activity of these electrodes for methanol electrooxidation. They demonstrated that the current density increased and that the onset potential for methanol electrooxidation also shifted over $200 \mathrm{mV}$ downward compared to the Ti/Pt nanoparticles. Additionally, iridium oxide exhibits good corrosion resistance in acid medium toward oxygen evolution.

Other studies have shown that the incorporating $\mathrm{IrO}_{2}$ into $\mathrm{Pt} / \mathrm{C}$ or $\mathrm{PtRu} / \mathrm{C}$ can reduce the potential values for ethanol electrooxidation. ${ }^{25}$ Ribeiro et al. ${ }^{1}$ found out that the addition of iridium to $\mathrm{Pt} / \mathrm{C}$ and $\mathrm{PtSn} / \mathrm{C}$ catalysts can lead to higher electrocatalytic activity for ethanol oxidation. Cao et al. ${ }^{26}$ demonstrated the high activity of $\mathrm{Ir} / \mathrm{C}$ and $\mathrm{Ir}_{3} \mathrm{Sn} / \mathrm{C}$ for ethanol electrooxidation. In DEFC experiments, the $\mathrm{Ir} / \mathrm{C}$ catalyst displayed performance similar to $\mathrm{Pt} / \mathrm{C}$, and $\mathrm{Ir}_{3} \mathrm{Sn} / \mathrm{C}$ showed activity similar to $\mathrm{Pt}_{3} \mathrm{Sn} / \mathrm{C}$. This finding indicates that Ir is an excellent candidate to substitute or reduce the amount of $\mathrm{Pt}$ in electrocatalysts. Nevertheless, $\mathrm{IrO}_{2}$ is extensively used in the preparation of mixed oxide electrodes, and numerous reports have suggested the application of Ir and its oxides in fuel cell systems. ${ }^{22,27-29}$

Indeed, results obtained through in situ Fourier transform infrared (FTIR) studies for ethanol electrooxidation on Ir electrodes ${ }^{30}$ (Pt electrodes containing some Ir or its oxides and quaternary electrocatalysts) showed that these systems perform well for ethanol oxidation in a direct ethanol fuel cell.

Considering these results, it is evident that the presence of Ir in the electrocatalyst has a synergetic effect (generally with $\mathrm{Pt}$ ) for both ethanol oxidation and direct ethanol fuel cell performance. Therefore, the aim of this work is to produce an optimized PtSnIr/C electrocatalyst, prepared by polymeric precursor method, to be used for both ethanol oxidation and as anode in a direct ethanol fuel cell. The main goals are to reduce the Pt content and to better understand the role of Ir in the ethanol oxidation reaction.

\section{Experimental}

\section{Preparation of PtSnlr/C electrocatalysts}

The PtSnIr/C electrocatalyst with a Pt:Sn:Ir atomic ratio of 1:1:1 was prepared by the polymeric precursor method reported by De Souza et al. ${ }^{13,16,31}$. For this purpose, a mass ratio of 1:50:400 (metallic precursor:citric acid (CA):ethylene glycol (EG)) was used to prepare the polymeric resin. Chloroplatinic acid $\left(\mathrm{H}_{2} \mathrm{PtCl}_{6} \cdot 6 \mathrm{H}_{2} \mathrm{O}\right.$, Sigma-Aldrich), tin chloride $\left(\mathrm{SnCl}_{2} \cdot 2 \mathrm{H}_{2} \mathrm{O}\right.$, Merck) and iridium chloride were used as metallic precursors. The prepared polymeric resin was stored under refrigeration. The catalyst was prepared by placing a pre-determined volume of resin in an appropriate amount of carbon Vulcan XC-72 (Cabot Corporation) to give a total metal loading of $20 \mathrm{wt} . \%$, followed by the addition of a sufficient amount of EG to cover the carbon powder. The pre-determined volume of resin was chosen to yield a final product containing equal atomic contents of $\mathrm{Pt}, \mathrm{Sn}$ and Ir. The mixture was homogenized in an ultrasonic bath for $60 \mathrm{~min}$ and then thermally treated at $400{ }^{\circ} \mathrm{C}$ for $2 \mathrm{~h}$ in a $\mathrm{N}_{2}$ atmosphere.

\section{Material characterization}

The catalyst morphology and particle sizes were obtained using JEOL 3010 HR-TEM (high resolution transmission electron microscopy) and JEOL JSM-5900LV microscopes. X-ray diffraction (XRD) patterns of the catalyst samples were recorded in a Rigaku Miniflex diffractometer using $\mathrm{Cu} \mathrm{K}_{\alpha}$ radiation $(1.5406 \AA$, $30 \mathrm{kV}$ and $15 \mathrm{~mA})$. XPS measurements were carried out using a commercial spectrometer (UNI-SPECS UHV). The $\mathrm{Mg} \mathrm{K}_{\alpha}$ line was used $(\mathrm{hv}=1253.6 \mathrm{eV})$, and the analyzer pass energy was set to $10 \mathrm{eV}$. The inelastic background of the C 1s, O 1s, Ir 4f, Pt 4f and Sn 3d electron core-level spectra was subtracted using Shirley's method. The binding energies of the spectra were corrected using the hydrocarbon component of adventitious carbon, fixed at $285.0 \mathrm{eV}$. The composition of the carbon-supported catalyst was determined from the ratios of the relative peak areas, corrected by sensitivity factors for the corresponding elements. The spectra were fitted without placing constraints using multiple Voigt profiles. The width at half maximum (FWHM) varied between 1.2 and $2.0 \mathrm{eV}$, and the accuracy of the peak positions was $\pm 0.1 \mathrm{eV}$.

\section{Electrocatalyst activity characterization}

In a single direct ethanol cell, the tested electrocatalyst anodes were PtSnIr/C and PtSn/C E-tek 20 wt.\%, whereas 
Pt/C E-tek 20 wt.\% was used as cathode in the gas diffusion electrodes. The electrocatalyst was painted over the GDL (carbon cloth Teflon treated Electrochem ECCC1-060T) in the form of a homogeneous dispersion prepared using Nafion ${ }^{\circledR}$ solution (5 wt.\%, Aldrich) and isopropanol (J. T. Baker). All electrodes contained $1 \mathrm{mg}$ of $\mathrm{Pt}$ per $\mathrm{cm}^{2}$ in the anode or in the cathode, except for PtSnIr/C, which contained $1 \mathrm{mg}$ of $\mathrm{Pt}$ and $\mathrm{Ir}$ per $\mathrm{cm}^{2}$. After the preparation, the electrodes were hot pressed on both sides of a Nafion ${ }^{\circledR} 117$ membrane at $100{ }^{\circ} \mathrm{C}$ for 2 min under a pressure of $225 \mathrm{kgf} \mathrm{cm}^{-2}$. Prior to use, the membranes were exposed to 3 wt. $\% \mathrm{H}_{2} \mathrm{O}_{2}$, thoroughly washed with distilled water and treated with $0.5 \mathrm{~mol} \mathrm{~L}^{-1} \mathrm{H}_{2} \mathrm{SO}_{4}$. The performance of the ethanol fuel cell containing each catalyst was determined in a single cell with an area of $5 \mathrm{~cm}^{2}$. The temperature was set to $100^{\circ} \mathrm{C}$ for the fuel cell and $80^{\circ} \mathrm{C}$ for the oxygen humidifier. The fuel $\left(2 \mathrm{~mol} \mathrm{~L}^{-1}\right.$ ethanol aqueous solutions) was delivered at approximately $2 \mathrm{~mL} \mathrm{~min}^{-1}$, the oxygen flow was set to $500 \mathrm{~mL} \mathrm{~min}^{-1}$, and the pressure was kept at 2 bar. Polarization curves were obtained using a TDI RBL 488 electronic load. The polarization curves were plotted using the data obtained with the potential measured in function of the current collected by the dynamic load, each polarization curve was performed under constant condition of aqueous ethanol and $\mathrm{O}_{2}$ flow. The potential was measured using a system consisting of a single cell connected to a dynamic load, that after a period of stabilization of the system running (approximately $2 \mathrm{~h}$ ) it was turned on to dynamic load at maximum current. The potential and current were measured every $10 \mathrm{~s}$ by reducing the current of 0.1 A per step until the open circuit potential. These conditions are standard to single cell experiments.

Additionally, the cell mechanism was studied by electrochemical experiments with a Solartron SI 1287 in acid media using an aqueous solution of $0.1 \mathrm{~mol} \mathrm{~L}^{-1} \mathrm{HClO}_{4}$ plus ethanol at three concentrations $\left(0.5,1\right.$ and $\left.2 \mathrm{~mol} \mathrm{~L}^{-1}\right)$. The preparation of the electrocatalyst film on the gold substrate was as follows. First, an electrocatalyst solution was prepared by dispersing $4 \mathrm{mg}$ of electrocatalyst powder in $1 \mathrm{ml}$ of water and mixing for $5 \mathrm{~min}$ in an ultrasonic bath. Then, $20 \mu \mathrm{l}$ of Nafion ${ }^{\circledR}$ solution $(5 \%)$ were added to the suspension and mixed again in an ultrasonic bath for $15 \mathrm{~min}$. Aliquots of $60 \mu \mathrm{L}$ of the dispersion fluid were pipetted on the surface $\left(0.78 \mathrm{~cm}^{2}\right)$ of the gold support. Finally, the electrode was dried at $60{ }^{\circ} \mathrm{C}$ for $20 \mathrm{~min}$ and hydrated for $5 \mathrm{~min}$ in water. The electrochemical cell was purged for 15 min with $\mathrm{N}_{2}$ before each experiment. The experiments were monitored using a Nexus 670 spectrometer (Nicolet) with an MCT (mercury cadmium telluride) detector. The experiments were carried out at controlled temperature $\left(25 \pm 1.0^{\circ} \mathrm{C}\right)$. Reflectance spectra were collected as the ratio of $R / R_{0}$, where $R$ represents a spectrum at a given potential and $\mathrm{R}_{0}$ is the spectrum collected at $0.05 \mathrm{~V}$. Positive and negative bands represent the consumption and production of substances, respectively. The spectra were recorded from the average of 128 interferograms.

\section{Results and Discussion}

Figure 1 shows a representative TEM image of the PtSnIr/C electrocatalyst and a particle size histogram. The size distributions were obtained measuring more than 300 particles. The micrograph reveals that the nanometric metal particles have a relatively straight size distribution (Table 1) and are uniformly dispersed on the support. It is important to note that $100 \%$ of the particles are between 1 and $10 \mathrm{~nm}$. The determined particle sizes are in agreement with those reported in the literature for the frequently used platinum-tin electrocatalysts. ${ }^{32-35}$
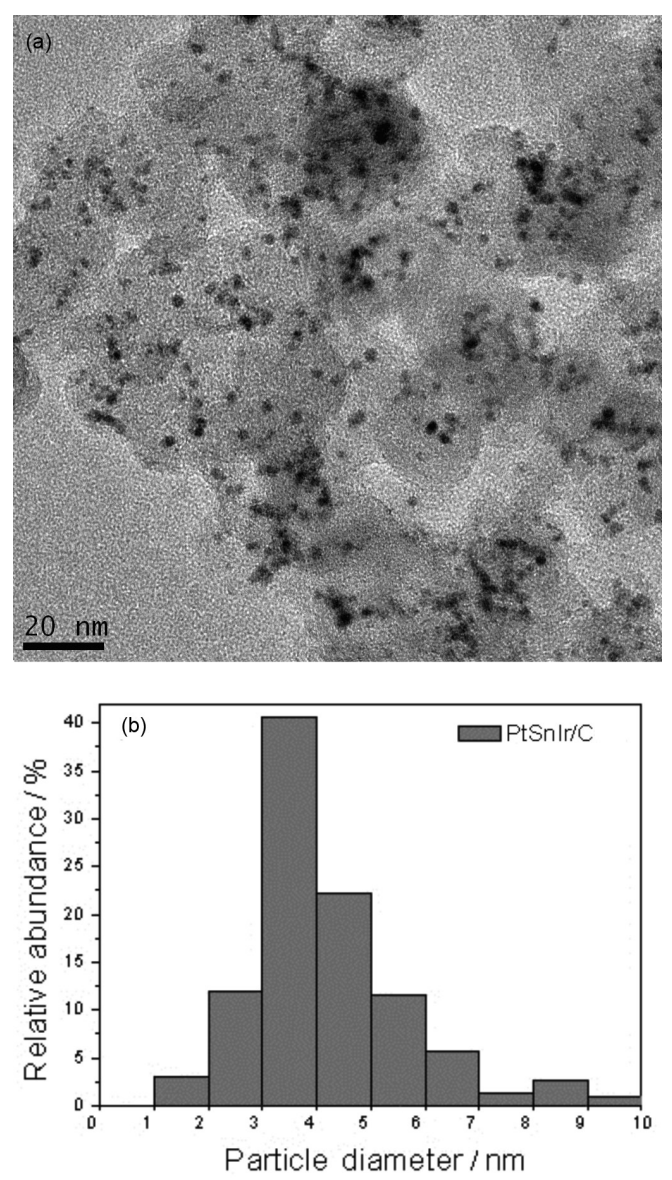

Figure 1. (a) TEM image of the PtSnIr/C electrocatalyst and (b) histogram of the catalyst mean particle diameter distribution over a size range of $0-10 \mathrm{~nm}$.

Figure 2 displays the XRD patterns of the carbonsupported PtSnIr $(1: 1: 1)$ ternary catalysts with a metal loading of $20 \mathrm{wt}$ \%. For reference, the Pt (solid line), Ir 
Table 1. Morphological information obtained from TEM images of the investigated catalysts

\begin{tabular}{lcccc}
\hline Electrocatalyst & Mean diameter $/ \mathrm{nm}$ & Standard deviation $/ \mathrm{nm}$ & Maximum diameter $/ \mathrm{nm}$ & Minimum diameter $/ \mathrm{nm}$ \\
\hline PtSnIr/C & 4.1 & 1.5 & 9.8 & 1.5 \\
\hline
\end{tabular}

(dotted line) and $\mathrm{IrO}_{2}$ (dashed line) peak patterns from cards JCPDF \# 04-802, JCPDF \# 87-715 and JCPDS \# 06-0598, respectively, were inserted. Compared to the reflections in bulk Pt (220) with $2 \theta / 67.53^{\circ}$, the diffraction peak for the ternary catalyst is shifted to a lower $2 \theta$ value $\left(66.93^{\circ}\right)$. In fact, the peak pattern at $2 \theta / 66.93^{\circ}$ is asymmetric, indicating the presence of more than one component, similar to the behavior already reported for $\mathrm{PtSn},{ }^{36} \mathrm{PtCo}^{37}$ and $\mathrm{PtRuIrSn}{ }^{18}$ catalysts. In this work, Lorentzian lineforms ${ }^{38}$ were used to deconvolute the four Bragg peaks located at $2 \theta / 39.44^{\circ}$, $45.85^{\circ}, 66.93^{\circ}$ and $80.03^{\circ}$.

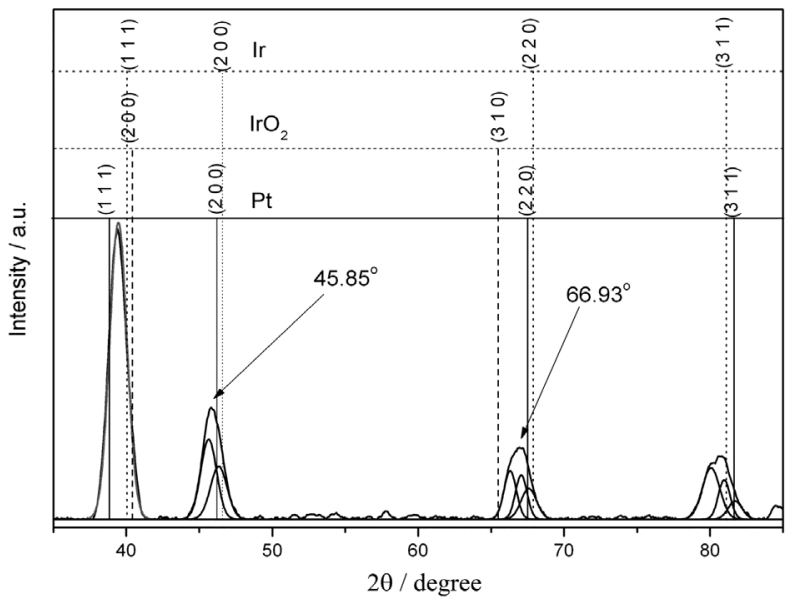

Figure 2. X-ray diffraction patterns of PtSnIr/C with the indicated peak patterns of $\mathrm{Pt}$, Ir and $\mathrm{IrO}_{2}$.

The peak at $2 \theta / 66.93^{\circ}$ was decomposed into three main peaks centered at $66.28^{\circ}, 67.08^{\circ}$ and $67.58^{\circ}$, as shown in Figure 2. The lattice parameters of these three components are $0.39853,0.39433$ and $0.39175 \mathrm{~nm}$, respectively. All three peaks displayed lattice parameter expansion due to lower $2 \theta$ values than those associated with $\mathrm{Pt}(0.39075 \mathrm{~nm})$ and $\operatorname{Ir}(0.38977 \mathrm{~nm})$. This suggests that $\mathrm{Sn}$ might be inserted into the Pt and/or Ir crystal structures as an alloy, as reported in several studies. ${ }^{1,13,18,19,26}$ The third component at $2 \theta / 67.58^{\circ}(0.39175 \mathrm{~nm})$ is close to $\mathrm{Pt}(220)$ reflection $\left(2 \theta / 67.53^{\circ}\right.$ and $\left.0.39075 \mathrm{~nm}\right)$, suggesting the possible segregation of a fraction of Pt. This is supported by the presence of components at $2 \theta / 46.28^{\circ}$ and $81.78^{\circ}$ of the other two reflections at $2 \theta / 45.85^{\circ}$ and $80.69^{\circ}$ ( $\mathrm{Pt}$, $2 \theta / 46.27^{\circ}$ and $81.37^{\circ}$ ). The possible segregation of a fraction of iridium $\left(2 \theta / 81.09^{\circ}\right)$ could be responsible for the component observed at $80.98^{\circ}$ of the (311) reflection $\left(2 \theta / 80.69^{\circ}\right)$. There was no evidence for the presence of crystalline $\mathrm{SnO}_{2}$ and $\mathrm{IrO}_{2}$, even though the existence of an amorphous phase cannot be ruled out.

The results obtained using X-ray diffraction analysis suggest a change in the electronic structure of PtSnIr compared to the pure metallic alloy constituents and a surface segregation of $\mathrm{Pt}$ and possibly also $\mathrm{Ir}^{39}$ Both phenomena could contribute to the electrocatalyst effects of our material discussed in the following sections.

To obtain further information of the characteristics of catalyst material, high resolution XPS spectra of Pt 4f, Ir 4f, Sn 3d, C 1s and O1s core levels were recorded. The results of the quantitative analysis indicate an equal atomic concentration of Pt and Sn. However, a lower Ir content than expected was obtained. The obtained element ratio of Pt:Sn:Ir was 1.0:1.0:0.3. This result indicates that the first mono-layers of the particle surface primarily consist of $\mathrm{Pt}$ and Sn phases. As shown in Figure 3a, the deconvoluted $\mathrm{Pt} 4 \mathrm{f}$ spectrum is formed by three spin-orbit doublets with the $\mathrm{Pt} 4 \mathrm{f}_{7 / 2}$ components at $71.6,72.3$ and $74.3 \mathrm{eV}$, attributed to metallic $\mathrm{Pt}, \mathrm{Pt}(\mathrm{OH})_{2}$ and $\mathrm{PtO}_{2}$ phases, respectively. ${ }^{40}$ The lower intensity of the Ir $4 \mathrm{f}$ spectrum (Figure 3a) overlaps with the X-ray $\alpha_{3 / 4} \mathrm{Pt} 4 \mathrm{f}$ satellites (peaks marked with black lines) making more difficulty the determination of the structural components for Ir. Consequently, despite the fact that binding energy of the fitted $\operatorname{Ir} 4 \mathrm{f}_{7 / 2}$ component is $61.8 \mathrm{eV}$, close to the position expected for $\mathrm{IrO}_{2}$, the presence of metallic iridium in the particles cannot be excluded. The $\mathrm{Sn} 3 \mathrm{~d}_{5 / 2}$ spectrum (Figure $3 \mathrm{~b}$ ) can be fitted with just one component, centered at $486.7 \mathrm{eV}$, indicating the coordination of tin with oxygen in the form of $\mathrm{SnO}_{2}{ }^{40}$ The corresponding component was identified in the $\mathrm{O} 1 \mathrm{~s}$ spectrum at $530.5 \mathrm{eV}$ (not shown). Evidence of the formation of a Pt/Sn or Ir/Sn alloy could not be obtained due to the weak second neighbor interaction of Sn with Pt or Ir. The XPS results suggest the structure of the particles with a metallic core formed by Pt and $\mathrm{Ir}\left(\right.$ or $\left.\mathrm{IrO}_{2}\right)$ decorated by $\mathrm{PtSnO}_{2}$ phase. The XPS results are key to the discussion of the electrocatalytical effect described in the next sections.

The performance in a real fuel cell is crucial for practical application. In Figure 4, an experiment with a single DEFC at $100{ }^{\circ} \mathrm{C}$ and with $\mathrm{O}_{2}$ as the cathodic oxidant is presented. The performance obtained could effectively reflect the catalytic effect of the anode catalysts. The open-circuit voltage (OCV) of the DEFC is about $754 \mathrm{mV}$ using the $\mathrm{PtSnIr} / \mathrm{C}$ electrocatalysts as the anode, which is $18 \mathrm{mV}$ lower than that obtained for the PtSn/C E-tek anode. 

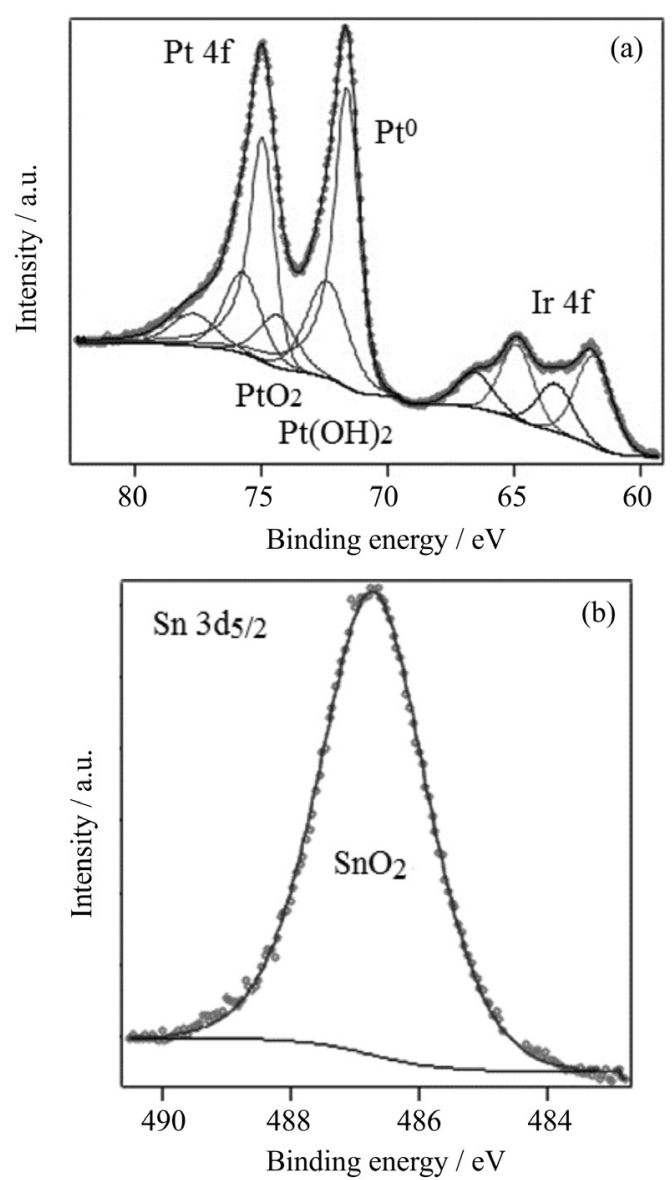

Figure 3. Fitted XPS core level spectra (a) Pt $4 \mathrm{f}$ and (b) $\mathrm{Sn} 3 \mathrm{~d}_{5 / 2}$ of the $\mathrm{PtSnIr} / \mathrm{C}$ catalyst.

However, the maximum power obtained using PtSnIr/C with half content of $\mathrm{Pt}$ is only slightly lower than that of the commercial material $\left(31.5 \mathrm{~mW} \mathrm{~cm}^{-2} \mathrm{vs.} 32.0 \mathrm{~mW} \mathrm{~cm}^{-2}\right.$, respectively). To the best of our knowledge, these results have not been reported for a catalyst with reduced Pt content, as proposed here. Some promising results have been already discussed in the literature using $\mathrm{PtSn} / \mathrm{C}$, $\mathrm{PtIr} / \mathrm{C}$ and PtSnIr/C. ${ }^{1,41}$ However, these results were obtained using $40 \%$ metal loading on carbon. In fact, the high power density found here for a catalyst with half content of $\mathrm{Pt}$, comparable to that obtained using a PtSn/C E-Tek anode, can be related to the presence of the main products generated during ethanol oxidation, as will be shown in the discussion of the FTIR results.

Figures $5 \mathrm{a}, 5 \mathrm{~b}$ and $5 \mathrm{c}$ present the FTIR spectra of ethanol oxidation for three different ethanol concentrations $\left(0.5,1\right.$ and $\left.2 \mathrm{~mol} \mathrm{~L}^{-1}\right)$ with increasing potential. They show the evolution of the bands associated with acetic acid $\left(1280 \mathrm{~cm}^{-1}\right){ }^{41}$ acetaldehyde $\left(933 \mathrm{~cm}^{-1}\right)^{15}$ and $\mathrm{CO}_{2}$ $\left(2343 \mathrm{~cm}^{-1}\right){ }^{42}$ The presence of $\mathrm{CO}$ at lower potentials was reported for ethanol oxidation using in situ FTIR for PtSnIr/C electrocatalyts, though with $0.2 \mathrm{~mol} \mathrm{~L}^{-1}$ ethanol and $40 \%$ of
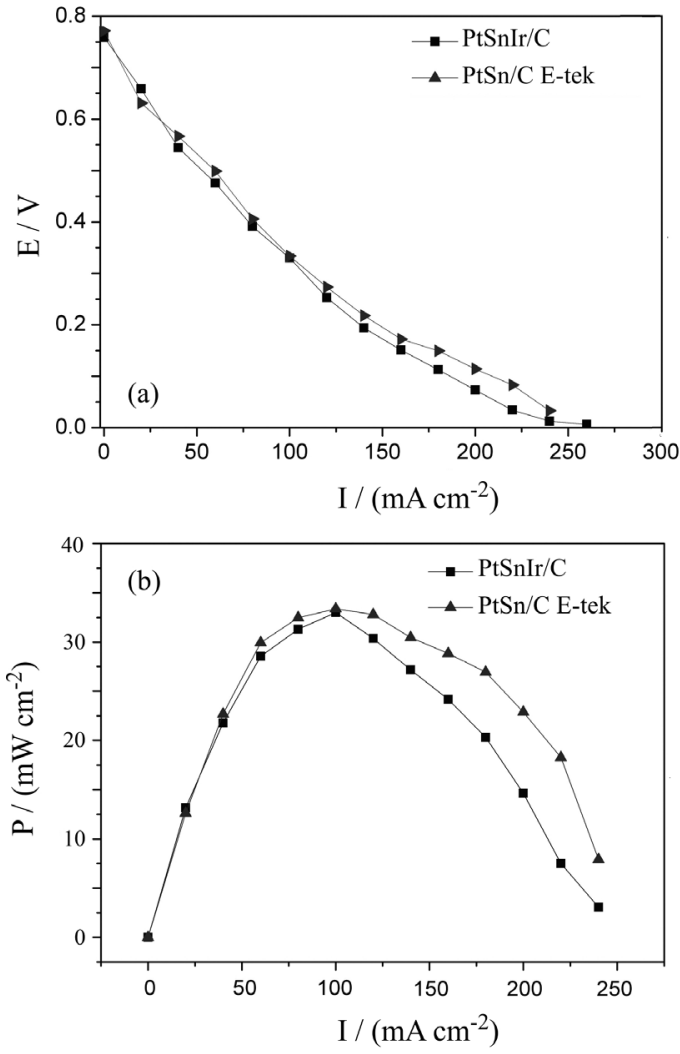

Figure 4. Polarization and power density curves in a $5 \mathrm{~cm}^{2}$ DEFC at $100{ }^{\circ} \mathrm{C}$ using (a) PtSnIr/C $\left(1 \mathrm{mg}_{\mathrm{Pt}+\text { Ir }} \mathrm{cm}^{-2}\right)$ or $20 \mathrm{wt} . \% \mathrm{PtSnIr} / \mathrm{C}$ and (b) PtSn/C E-tek as anode catalysts $\left(1 \mathrm{mg}_{\mathrm{P}_{\mathrm{t}}} \mathrm{cm}^{-2}\right)$ and $20 \mathrm{wt} . \% \mathrm{Pt} / \mathrm{C}$ E-tek as cathode catalyst $\left(1 \mathrm{mg}_{\mathrm{Pt}_{\mathrm{t}}} \mathrm{cm}^{-2}\right)$. Nafion ${ }^{\circledR} 117$ was used as membrane.

metal loading. In this work, it was not possible to observe the presence of $\mathrm{CO}$, this is probably because of high ethanol concentration, when the ethanol concentration is increased the $\mathrm{CO}_{2}$ decreased. ${ }^{42,43}$ The absence of adsorbed $\mathrm{CO}$ could be indicating its easy removal from the surface of the catalysts through $\mathrm{CO}_{2}$ formation. ${ }^{1}$ Another aspect that must be taken into account is that the reflection-absorption theory of IR was developed to smooth surface and there are experimental evidences that heterogeneous surfaces can cause a noticeable reduction of the band intensities referent to adsorbed species and consequently, important information concerning $\mathrm{CO}$ is often lost when investigating such surfaces. ${ }^{44}$ The results in this work may be indicative of the high conversion of ethanol to acetic acid and acetaldehyde for the ethanol concentrations used in this work, as found in a study using gas chromatography. ${ }^{40}$ In Figures $5 \mathrm{a}, 5 \mathrm{~b}$ and $5 \mathrm{c}$, it can also be observed the interfacial water band close to $1600 \mathrm{~cm}^{-1},{ }^{15}$ and the carbonyl band close to $1720 \mathrm{~cm}^{-1} .{ }^{45}$ It is important to stress that from a potential of $0.2 \mathrm{~V}$, the formation of the products from ethanol oxidation can be verified.

To associate the changes with increasing or decreasing concentrations of specific species produced during the ethanol oxidation, all bands were deconvoluted by 

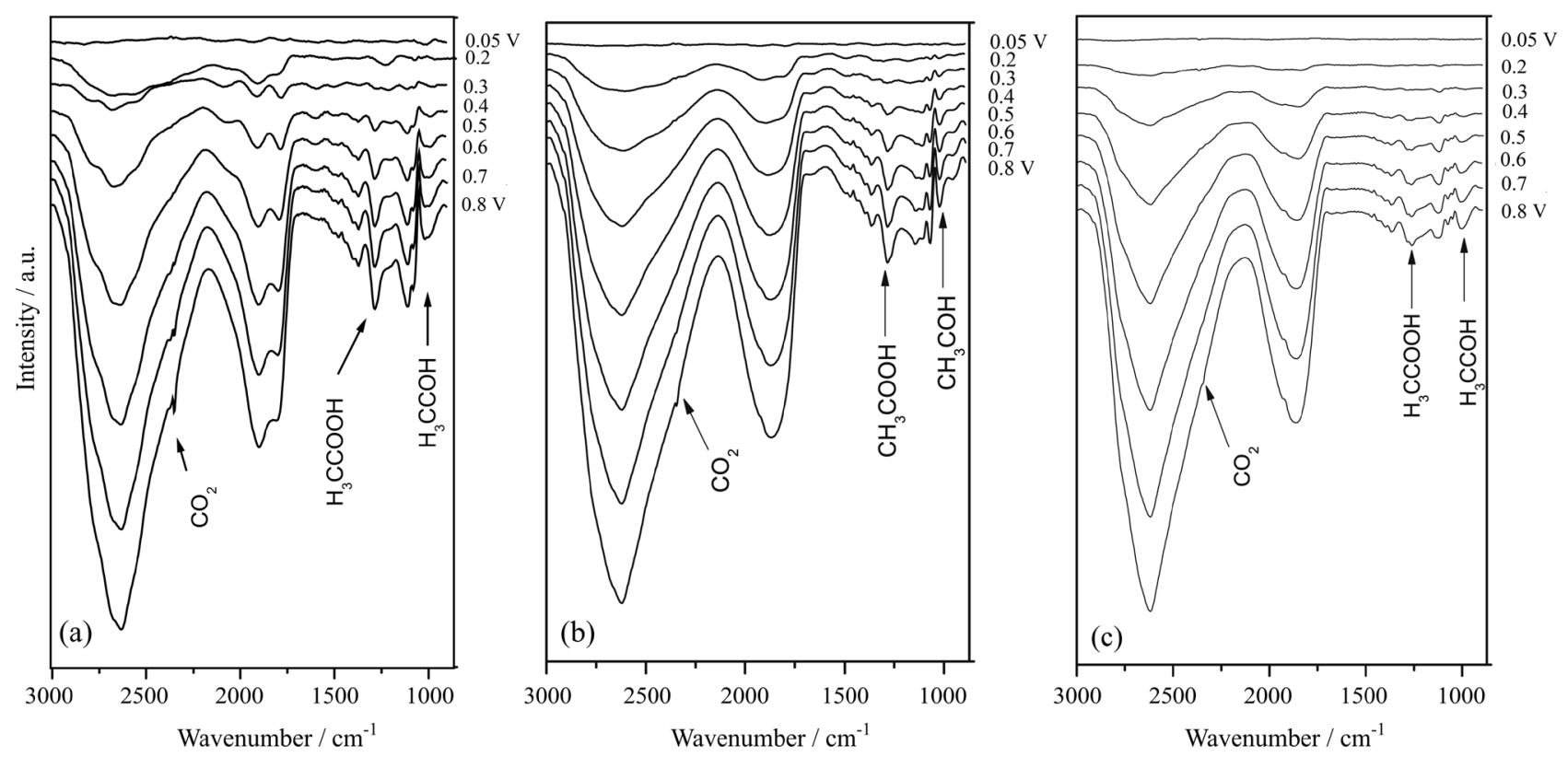

Figure 5. In situ FTIR spectra for a PtSnIr/C electrocatalyst in $0.1 \mathrm{~mol} \mathrm{~L}^{-1} \mathrm{HClO}_{4}$ in the presence of ethanol at concentrations of (a) 0.5 , (b) 1 and (c) $2 \mathrm{~mol} \mathrm{~L}^{-1}$. Reference spectra were taken at $0.05 \mathrm{~V}$. Sample spectra measured after applying successive potential steps of $0.1 \mathrm{~V}$, as indicated in the figure. Spectra were averaged from 128 scans. The spectral resolution was $8 \mathrm{~cm}^{-1}$ using a SeZn prismatic window.

Lorentzian lineforms. Thus, in this study, the intensity and alignment of each band were individually analyzed as a function of the potential (Figure 6), an approach that has not been previously applied for in situ FTIR analysis during ethanol oxidation using PtSnIr/C electrocatalysts.

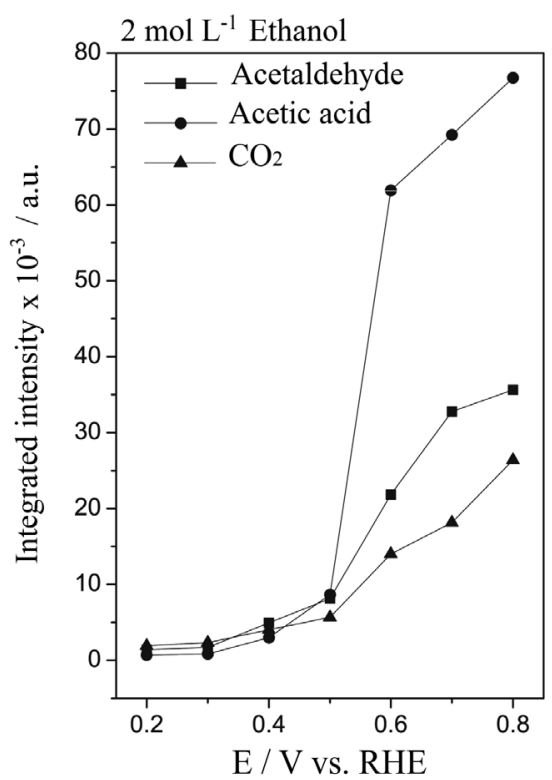

Figure 6. Integrated bands of the spectra set in Figure 5c, indicating the main products of ethanol oxidation.

The in situ FTIR integrated intensities for acetic acid, acetaldehyde and $\mathrm{CO}_{2}$ on PtSnIr/C electrocatalyst (in $2 \mathrm{~mol} \mathrm{~L}^{-1} \mathrm{CH}_{3} \mathrm{COOH}$ and $0.1 \mathrm{~mol} \mathrm{~L}^{-1} \mathrm{HClO}_{4}$ solution) are shown in Figure 6. It can be observed that the quantity of acetic acid, acetaldehyde and $\mathrm{CO}_{2}$ increases with increasing electrocatalyst electrode potential. The acetic acid formation begins at about $0.4 \mathrm{~V}$, whereas the $\mathrm{CO}_{2}$ formation starts at $0.5 \mathrm{~V}$.

Further investigations (presented in Figure 7) were performed examining the $\mathrm{CO}_{2}$ /acetic acid intensity ratio as a function of the electrode potential. The results show that the best efficiency related to the highest $\mathrm{CO}_{2}$ /acetic acid ratio was achieved in experiments using

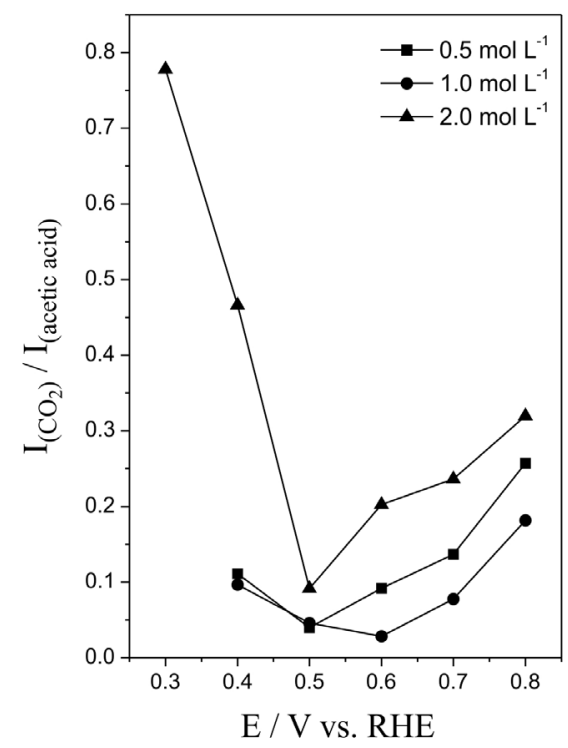

Figure 7. The ratio of integrated intensities of $\mathrm{CO}_{2}$ and acetic acid as a function of potential for the three ethanol concentrations in the solutions. 
$2 \mathrm{~mol} \mathrm{~L}^{-1}$ of ethanol. For $2 \mathrm{~mol} \mathrm{~L}^{-1}$ of ethanol, the PtSnIr/C electrocatalyst facilitates the production of $\mathrm{CO}_{2}$ at low potentials. However, $\mathrm{CO}_{2}$ formation rapidly decreases due to the faster formation of acetic acid, which agrees with the preferential oxidation route: ethanol to acetic acid rather than to $\mathrm{CO}_{2}$. In contrast, for $\mathrm{Pt} / \mathrm{C},{ }^{46}$ this ratio is smaller at low potentials and reaches a maximum at about $650 \mathrm{mV}$. Additionally, when comparing the results obtained here for ethanol oxidation using PtSnIr/C with those using $\mathrm{PtSn} / \mathrm{C}$ E-tek for the same process, ${ }^{43}$ the latter catalyst displays a lower production of acetic acid in all potential regions and a higher production of $\mathrm{CO}_{2} \cdot{ }^{43}$

The interesting point here is the role of iridium as an electrocatalyst. Some authors ${ }^{26,30}$ reported that iridium content in the electrocatalyst could favor acetaldehyde at low potentials when the surface was partially covered by $\mathrm{CO}_{\text {ads }}$ and $\mathrm{H}_{\text {ads }}$. Furthermore, Gyenge et al. ${ }^{47}$ revealed the favorable thermodynamics of $\mathrm{OH}_{\text {ads }}$ dissociation on Ir compared to $\mathrm{Pt}$ by the weak binding of $\mathrm{H}_{2} \mathrm{O}$ to the $\mathrm{Ir}$ surface, ${ }^{26,48}$ which also favors a bifunctional mechanism. Furthermore, the detection of a larger quantity of acetic acid (more oxidized species) in the product of the DEFC using a PtIrSn/C (20:5:15) anode is a further indication of the efficiency of the catalyst. ${ }^{40}$ Consequently, the PtSnIr/C catalyst supports a mechanism in which the surface oxides facilitate the $\mathrm{CO}$ stripping of $\mathrm{Pt}$ atoms by providing oxygenated species for the $\mathrm{CO}\left(\mathrm{IrO}_{2}\right.$ phase was identified using XPS). These oxygenated species can also react with ethanol or acetaldehyde adsorbed on the electrocatalyst producing acetic acid, i.e., a bifunctional mechanism. ${ }^{49}$ However, an electronic effect cannot be excluded for two main reasons: (i) X-ray diffraction patterns indicated a change in the lattice parameter of Pt and/or Ir in the presence of Sn and (ii) because using XPS, the formation of a core-decorated with metal structure was suggested, and there are domains in which the electronic effect should be operating. Additionally, the core-decorated with metal structure evidenced by XPS can be an opened structure in which $\mathrm{SnO}_{2}$ and $\mathrm{IrO}_{2}$ are exposed and join with $\mathrm{Pt}$, increasing the bifunctional mechanism.

Based on the reported data and the results discussed above, it can be concluded that $\operatorname{IrO}_{2}$ facilitates a bifunctional mechanism incorporating both $\mathrm{SnO}_{2}$ and Pt. In contrast, it is not possible to exclude an electronic effect either by the modification of the lattice parameters of Pt and Ir by the presence of Sn or the effect of a coredecorated with metal structure, as evidenced by XPS measurements. The presence of Ir helps to produce $\mathrm{CO}_{2}$ at low potentials and also produces more acetic acid than $\mathrm{CO}_{2}$ at higher potentials. Hence, it is possible to reduce the Pt content to half of that commonly used for the commercial PtSn/C material without any loss of power density of the fuel cell.

\section{Conclusions}

The PtSnIr/C electrocatalyst prepared by the polymeric precursor method presents a mixed system of different pure alloy phases or even a core-shell structure, such as shown from the results of XRD and XPS experiments. It was demonstrated that, in DEFC, the electrocatalyst displays performance similar to $\mathrm{PtSn} / \mathrm{C}$ E-tek, however, with half content of platinum. The FTIR analysis of the ethanol oxidation showed that at lower potentials, acetaldehyde, acetic acid and $\mathrm{CO}_{2}$ were the main reaction products involving very limited $\mathrm{CO}$ production. Based on the obtained results, it is evident that the utilization of Ir can considerably reduce Pt usage in the electrocatalyst, providing an equal power density compared to the commercial PtSn/C material.

\section{Acknowledgments}

The authors wish to thank the Brazilian Funding Institutions Conselho Nacional de Desenvolvimento Científico e Tecnológico (CNPq) (Process No. 474732/2008-8), Coordenação de Aperfeiçoamento de Pessoal de Nível Superior (CAPES), FAPESP (Processes No. 05/59992-6, 09/09145-6, 10/07831-7, 10/16511-6), Instituto Nacional de Ciência e Tecnologia (INCT) de Energia e Meio Ambiente (Process Number. 573.783/2008-0). Additionally, the authors wish to thank both the PhD students (Emerson P. Boscheto and Bruno C. Batista) and Professor Hamilton Brandão Varela de Albuquerque - Instituto de Química de São Carlos - USP for in situ FTIR measurements.

\section{References}

1. Ribeiro, J.; dos Anjos, D. M.; Kokoh, K. B.; Coutanceau, C.; Léger, J. M.; Olivi, P.; de Andrade, A. R.; Tremiliosi-Filho, G.; Electrochim. Acta 2007, 52, 6997.

2. Li, H.; Sun, G.; Cao, L.; Jiang, L.; Xin, Q.; Electrochim. Acta 2007, 52, 6622.

3. Bergamaski, K.; Pinheiro, A. L. N.; Teixeira-Neto, E.; Nart, F. C.; J. Phys. Chem. B 2006, 110, 19271.

4. Hotza, D.; Costa, J. C. D.; Int. J. Hydrogen Energy 2008, 33, 4915.

5. Chang, Y.-W.; Liu, C.-W.; Wei, Y.-C.; Wang, K.-W.; Electrochem. Commun. 2009, 11, 2161.

6. Vigier, F.; Coutanceau, C.; Hahn, F.; Belgsir, E. M.; Lamy, C.; J. Electroanal. Chem. 2004, 563, 81. 
7. Giz, M. J.; Camara, G. A.; Maia, G.; Electrochem. Commun. 2009, 11, 1586.

8. Wang, H.; Jusys, Z.; Behm, R. J.; J. Power Sources 2006, 154, 351.

9. Camara, G. A.; de Lima, R. B.; Iwasita, T.; Electrochem. Commun. 2004, 6, 812.

10. Colmati, F.; Antolini, E.; Gonzalez, E. R.; J. Power Sources 2006, 157, 98.

11. Zhou, W. J.; Li, W. Z.; Song, S. Q.; Zhou, Z. H.; Jiang, L. H.; Sun, G. Q.; Xin, Q.; Poulianitis, K.; Kontou, S.; Tsiakaras, P.; J. Power Sources 2004, 131, 217.

12. Silva, J. C. M.; De Souza, R. F. B.; Parreira, L. S.; Neto, E. T.; Calegaro, M. L.; Santos, M. C.; Appl. Catal., B 2010, 99, 265.

13. De Souza, R. F. B.; Parreira, L. S.; Rascio, D. C.; Silva, J. C. M.; Teixeira-Neto, E.; Calegaro, M. L.; Spinace, E. V.; Neto, A. O.; Santos, M. C.; J. Power Sources 2010, 195, 1589.

14. Kowal, A.; Gojkovic, S. L.; Lee, K. S.; Olszewski, P.; Sung, Y. E.; Electrochem. Commun. 2009, 11, 724.

15. Li, M.; Kowal, A.; Sasaki, K.; Marinkovic, N.; Su, D.; Korach, E.; Liu, P.; Adzic, R. R.; Electrochim. Acta 2010, 55, 4331.

16. De Souza, R. F. B.; Flausino, A. E. A.; Rascio, D. C.; Oliveira, R. T. S.; Neto, E. T.; Calegaro, M. L.; Santos, M. C.; Appl. Catal., B 2009, 91, 516.

17. Wang, J.; Xi, J.; Bai, Y.; Shen, Y.; Sun, J.; Chen, L.; Zhu, W.; Qiu, X.; J. Power Sources 2007, 164, 555.

18. Fatih, K.; Neburchilov, V.; Alzate, V.; Neagu, R.; Wang, H.; J. Power Sources 2010, 195, 7168.

19. Cao, L.; Sun, G.; Li, H.; Xin, Q.; Fuel Cells Bull. 2007, 2007, 12.

20. Ioroi, T.; Yasuda, K.; J. Electrochem. Soc. 2005, 152, A1917.

21. Ioroi, T.; Kitazawa, N.; Yasuda, K.; Yamamoto, Y.; Takenaka, H.; J. Electrochem. Soc. 2000, 147, 2018.

22. Sivakumar, P.; Tricoli, V.; Electrochem. Solid-State Lett. 2006, 9, A167.

23. Liang, Y. M.; Zhang, H. M.; Zhong, H. X.; Zhu, X. B.; Tian, Z. Q.; Xu, D. Y.; Yi, B. L.; J. Catal. 2006, 238, 468.

24. Chen, A. C.; La Russa, D. J.; Miller, B.; Langmuir 2004, 20, 9695.

25. Calegaro, M. L.; Suffredini, H. B.; Machado, S. A. S.; Avaca, L. A.; J. Power Sources 2006, 156, 300.

26. Cao, L.; Sun, G.; Li, H.; Xin, Q.; Electrochem. Commun. 2007, 9, 2541.

27. Birss, V. I.; Andreas, H.; Serebrennikova, I.; Elzanowska, H.; Electrochem. Solid-State Lett. 1999, 2, 326.

28. Liao, S. J.; Holmes, K. A.; Tsaprailis, H.; Birss, V. I.; J. Am. Chem. Soc. 2006, 128, 3504.

29. Tsaprailis, H.; Birss, V. I.; Electrochem. Solid-State Lett. 2004, 7, A348.

30. de Tacconi, N. R.; Lezna, R. O.; Beden, B.; Hahn, F.; Lamy, C.; J. Electroanal. Chem. 1994, 379, 329.
31. Polo, A. S.; Santos, M. C.; de Souza, R. F. B.; Alves, W. A.; J. Power Sources 2011, 196, 872.

32. Purgato, F. L. S.; Olivi, P.; Léger, J. M.; de Andrade, A. R.; Tremiliosi-Filho, G.; Gonzalez, E. R.; Lamy, C.; Kokoh, K. B.; J. Electroanal. Chem. 2009, 628, 81.

33. Colmati, F.; Antolini, E.; Gonzalez, E. R.; Electrochim. Acta $\mathbf{2 0 0 5}, 50,5496$

34. Jiang, L.; Sun, G.; Zhou, Z.; Zhou, W.; Xin, Q.; Catal. Today 2004, 93-95, 665.

35. Zhu, M.; Sun, G.; Li, H.; Cao, L.; Xin, Q.; Chin. J. Catal. 2008, $29,765$.

36. García-Rodríguez, S.; Somodi, F.; Borbáth, I.; Margitfalvi, J. L.; Peña, M. A.; Fierro, J. L. G.; Rojas, S.; Appl.Catal., B 2009, $91,83$.

37. Aricò, A. S.; Shukla, A. K.; Kim, H.; Park, S.; Min, M.; Antonucci, V., Appl. Surf. Sci. 2001, 172, 33.

38. Allmann, R. In Powder Diffraction: Theory and Practice; Dinnebier, R. E., Billinge, S. J. L., eds.; The Royal Society of Chemistry: Cambridge, 2008.

39. Demirci, U. B.; J. Power Sources 2007, 173, 11.

40. Moulder, J. F.; Stickle, W. F.; Sobol, P. E.; Bomben, K. D.; Handbook of X-ray Photoelectron Spectroscopy; Ed. J. Chastain, Perkin-Elmer Corporation, Physical Electronics Division, Eden Prairie, Minnesota, USA, 1992.

41. Tayal, J.; Rawat, B.; Basu, S.; Int. J. Hydrogen Energy 2011, $36,14884$.

42. Camara, G. A.; Iwasita, T.; J. Electroanal. Chem. 2005, 578, 315.

43. De Souza, R. F. B.; Parreira, L. S.; Silva, J. C. M.; Simões, F. C.; Calegaro, M. L.; Giz, M. J.; Camara, G. A.; Neto, A. O.; Santos, M. C.; Int. J. Hydrogen Energy 2011, 36, 11519.

44. Lima, R. B. ; Paganin, V.; Iwasita, T.; Vielstich, W.; Electrochim. Acta 2003, 52, 81.

45. Xia, X. H.; Liess, H. D.; Iwasita, T.; J. Electroanal. Chem. 1997, 437, 233.

46. Lima, F. H. B.; Gonzalez, E. R.; Electrochim. Acta 2008, 53, 2963.

47. Gyenge, E.; Atwan, M.; Northwood, D.; J. Electrochem. Soc. 2006, 153, A150.

48. Kua, J.; Goddard, W. A.; J. Am. Chem. Soc. 1999, 121, 10928.

49. Tong,Y.Y.; Kim, H. S.; Babu, P. K.; Waszczuk, P.; Wieckowski, A.; Oldfield, E.; J. Am. Chem. Soc. 2002, 124, 468.

Submitted: November 25, 2011

Published online: June 5, 2012

FAPESP has sponsored the publication of this article. 